Annals of Warsaw University of Life Sciences - SGGW

Land Reclamation No 47 (1), 2015: 69-85

(Ann. Warsaw Univ. Life Sci. - SGGW, Land Reclam. 47 (1), 2015)

\title{
Investigations of hydraulic operating conditions of air lift pump with three types of air-water mixers
}

\author{
MAREK KALENIK \\ Department of Civil Engineering, Warsaw University of Life Sciences - SGGW
}

\begin{abstract}
Investigations of hydraulic operating conditions of air lift pump with three types of air-water mixers. The paper presents the analysis of results of the investigations concerning the influence of various constructive solutions of the air-water mixers on hydraulic operating conditions of the air lift pump. The scope of the investigations encompassed the determination of characteristics of delivery head and delivery rate for three types of air-water mixers applied in the constructed air lift pump. Using the obtained results, the efficiency of the three types of air-water mixers applied in this air lift pump was determined. The analysis was carried out and there was checked whether the improved analytical Stenning-Martin model can be used to design air lift pumps with the air-water mixers of these types. The highest capacity in the water transport was reached by the air lift pump with the $1^{\text {st }}$ type air-water mixer, the lowest one - with the $3^{\text {rd }}$ type air-water mixer. The water flow in the air lift pump increases along with the rise in the air flow. The lower are the hydraulic losses generated during flow of the air flux by the air-water mixer, the higher is the air lift pump capacity. Along with the rise in the water delivery head, the capacity of the air lift pump decreases. The highest efficiency is reached by the air lift pump with the $1^{\text {st }}$ type air-water mixer, the lowest - with the $3^{\text {st }}$ type air-water mixer. The efficiency of the air lift pump for the three investigated types of air-water mixers decreases along with the rise in air flow rate and water delivery head. The values of submergence ratio $(h / L)$ of the delivery pipe, calculated with the use of the improved analytical Stenning-Martin model, coincide quite well with the values of $h / L$ determined from the measurements.
\end{abstract}

Key words: air lift pump (Mammoth pump), air-water mixer, water flow, air flow

\section{INTRODUCTION}

Air lift pumps (Mammoth pumps) used to be applied to transport fluids both in pipeline and sewerage systems. Nowadays, in Poland, the air lift pumps are applied to lift fluids and sediments in small near-home container sewage-treatment plants and big group sewage-treatment plants as well as in high-rate filters with self-regenerating bed (Heidrich et al. 2008, Kalenik 2009) or for renovation of bored wells (Solecki 2010). However, in other countries, the air lift pumps have much wider application. They are used to aerate and mix water as well as to remove carbon dioxide from water in the industrial fish farming (Barrut et al. 2012), to mix water in deep lakes and to aerate it by means of transport of water from the lake bed onto its surface (Parker 1983, Fan et al. 2013). Due to the simple construction and high reliability of the air lift pumps, they are applied in various branches of industry, especially in the petrochemical industry to raise oil from dead wells (Hanafizadeh et al. 2011), in the chemical industry to transport corrosive, radioactive, arid or toxic 
fluids (De Cachard and Delhaye 1996, Kassab et al. 2007) as well as to pump boiling fluids, where the change of liquid phase into gas phase occurs (Khalil et al. 1999). They are also used to transport suspensions in mining industry and to lift manganese concretions from deep seabed up to ca. 4000-6000 m (Kassab et al. 2007).

A two-phase (liquid-gas) or threephase (liquid-gas-solid) flow exists in the air lift pumps which is very difficult for mathematical modeling, for it depends on many factors and variables (Kalenik 2008, 2014). The hydraulic operating conditions of two- and threephase flow in the air lift pumps are very poorly identified (Kassab et al. 2007). There are made some attempts to identify flow structures, occurring in various conditions of liquid-gas flow or liquidgas-solid flow, and to work out so-called flow structure maps for them and mathematical models for simulation of flows occurring in the air lift pumps (De Cachard and Delhaye 1996, Yoshinaga and Sato 1996, Kassab et al. 2007, 2009, Hanafizadeh et al. 2011, Mahrous 2012, 2013b, 2014, Fan et al. 2013, Meng et al. 2013, Kim et al. 2014). Investigations were also carried out for the air lift pumps made of perpendicular (Esen 2010) and curved (Fujimoto et al. 2004) pipes. The performed investigations of the air lift pumps with curved pipes beyond the air-water mixer show that significantly falls the delivery of pumping of solids in the air lift pumps constructed in such way. However, if only liquid is being pumped, the pipe curvature of the air lift pump does not affect its delivery
(Mahrous 2013a). From the performed tests appears that the air lift pumps are characterized by the low efficiency of operation if compared to conventional pumps (Kassab et al. 2007, 2009, Tighzert et al. 2013).

There is few information on rules of the dimensioning and construction of the air lift pumps in the accessible scientific and technical literature (Jankowski 1975, Wurts et al. 1994). Especially, there is no information how to design an air-water mixer to obtain the best operating parameters.

In aim to calculate the operational efficiency of the investigated air-water mixers in the constructed air lift pump, the Nicklin's formula (Nicklin 1963), will be used:

$$
\eta=\frac{\rho g Q_{w}(L-h)}{p_{b} Q_{p} \ln \left(\frac{p_{p}}{p_{b}}\right)}
$$

where:

$Q_{w}$ - water flow rate $\left(\mathrm{m}^{3} \cdot \mathrm{s}^{-1}\right)$,

$Q_{p}$ - air flow rate $\left(\mathrm{m}^{3} \cdot \mathrm{s}^{-1}\right)$,

$p_{p}$ - air pressure $\left(\mathrm{N} \cdot \mathrm{m}^{-2}\right)$,

$\rho-$ liquid density $\left(\mathrm{kg} \cdot \mathrm{m}^{-3}\right)$,

$p_{b}$ - barometric pressure $\left(\mathrm{N} \cdot \mathrm{m}^{-2}\right)$,

$h$ - delivery pipe submergence length $(\mathrm{m})$,

$L$ - delivery pipe length-to-outlet (m),

$g$ - gravitational acceleration $\left(\mathrm{m} \cdot \mathrm{s}^{-2}\right)$.

However, in aim to analyze the obtained results, the improved analytical Stenning-Martin model, constructed of the following equations (Wahba et al. 2014) will be used: 


$$
\frac{h}{L}=\frac{Q_{w}^{2}}{2 g L A^{2}}\left[\left(\frac{f L}{d}+1\right)+\left(\frac{f L}{d}+2\right) \frac{Q_{p}}{Q_{w}}\right]+\frac{1}{1+\frac{Q_{w}}{s Q_{p}}}
$$

$$
s=1.2+0.2 \frac{Q_{p}}{Q_{w}}+\frac{0.35 A \sqrt{g d}}{Q_{w}}
$$

$$
\frac{1}{\sqrt{f}}=-2 \log \left(\frac{\frac{\varepsilon}{d}}{3.7}+\frac{2.51}{\operatorname{Re} \sqrt{f}}\right)
$$$$
\varepsilon=\frac{k}{d}
$$

$$
\begin{aligned}
& A=\frac{\pi d^{2}}{4} \\
& \operatorname{Re}=\frac{4 Q_{w}}{\pi d v}
\end{aligned}
$$

where:

$h / L$ - delivery pipe submergence ratio (-),

$Q_{w}$ - water flow rate $\left(\mathrm{m}^{3} \cdot \mathrm{s}^{-1}\right)$,

$Q_{p}$ - air flow rate $\left(\mathrm{m}^{3} \cdot \mathrm{s}^{-1}\right)$,

$h$ - delivery pipe submergence length $(\mathrm{m})$,

$L$ - delivery pipe length-to-outlet (m),

$g$ - gravitational acceleration $\left(\mathrm{m} \cdot \mathrm{s}^{-2}\right)$,

$d$ - vertical pipe diameter $(\mathrm{m})$,

$s \quad-$ slip ratio (-),

$f-$ friction factor $(-)$,

$\varepsilon-$ relative roughness $(-)$,

$k-$ absolute roughness (m),

$A$ - vertical pipe cross-sectional area $\left(\mathrm{m}^{2}\right)$,

Re - Reynolds number (-),

$v-$ liquid kinematic viscosity $\left(\mathrm{m}^{2} \cdot \mathrm{s}^{-1}\right)$.
The paper presents the analysis of results of the investigations concerning the influence of various constructive solutions of the air-water mixers on hydraulic operating conditions of the air lift pump. The scope of the investigations encompassed the determination of characteristics of delivery head, delivery rate and operational efficiency for three types of air-water mixers applied in the constructed air lift pump as well as the analysis of possibilities of the use of the improved analytical Stenning-Martin model in design of air lift pumps with these types of air-water mixers.

\section{DESCRIPTION OF MEASURING STAND}

Figure 1 shows the construction and operating principle of the stand for investigations of hydraulic operating conditions of the air lift pump. After opening of the ball valve (6), the pipeline (5) delivers water to the plastic tank (7) with the capacity of 4501 . During the tests the tank (7) was permanently filled with water up to the height of $1.0 \mathrm{~m}$. The excess of the water delivered to the tank (7) was carried after opening of the ball valve (12) by the overfall (11) to the sewerage through the floor inlet (15). The draining pipeline (13) served to empty the tank (7) from the water after the ball valve (14) opening. 


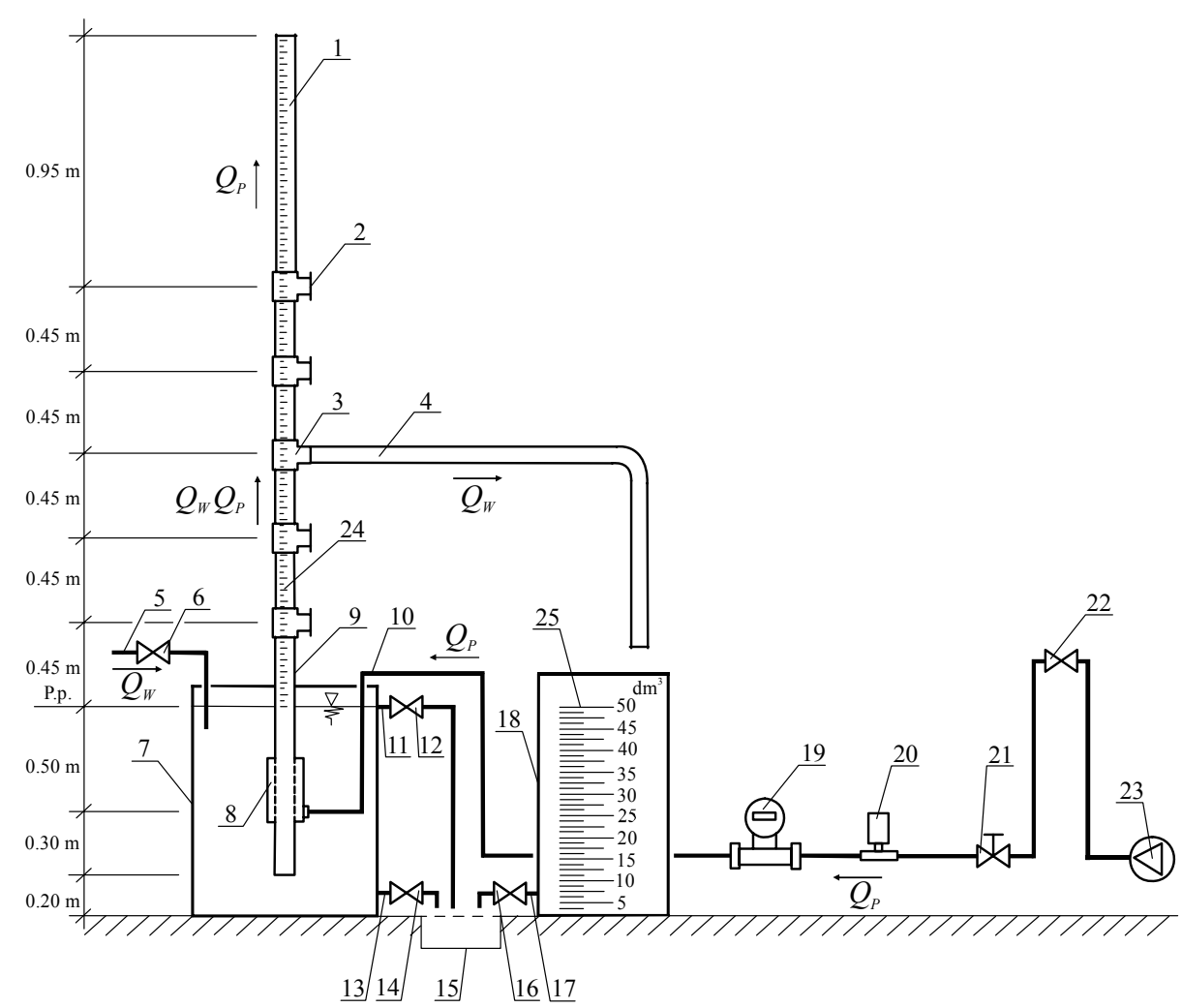

FIGURE 1. Scheme of the stand for investigations of the air lift pump: 1 - breather, 2 - measuring tee, closed with cork, 3 - measuring tee, 4 - water carrying pipe, 5 - water supplying pipe, $6,12,14,16,22$ - ball cut-off valve, 7 - tank, 8 - air-water mixer, 9 - transparent delivery pipe, 10 - air supplying pipe, 11 - overfall, 13, 17 - draining pipe, 15 - floor inlet, 18 - measuring container, 19 - electronic air flow meter, 20 - electronic manometer, 21 - poppet valve, 23 - compressor, 24,25 - scale

Inside of the tank (7), at the height of $0.20 \mathrm{~m}$ upon its bottom, the transparent plastic delivery pipe (9) with the internal diameter of $0.04 \mathrm{~m}$ and the height of $4.0 \mathrm{~m}$ was mounted, at which the scale (24) was placed to measure the air lift pump delivery head. To measure the air lift pump delivery rate, five measuring pipe tees (3) were mounted in the delivery pipe (9), at the heights of $0.45,0.90$, $1.35,1.80$ and $2.25 \mathrm{~m}$ measured over the water level in the tank (7). The upper section of the delivery pipe (9) consti- tutes the air lift pump breather (1) operating during its work. The air-water mixer (8) was mounted in the delivery pipe (9) at the height of ca. $0.30 \mathrm{~m}$ over its lower edge.

Figure 2 shows constructive solutions of the tested air-water mixers. The $1^{\text {st }}$ type mixer (Fig. 2a) is a one-point air supplying element of the air lift pump in a form of an externally threaded steel end (2) with the internal diameter of $0.013 \mathrm{~m}$, mounted at the height of $0.30 \mathrm{~m}$ over the 

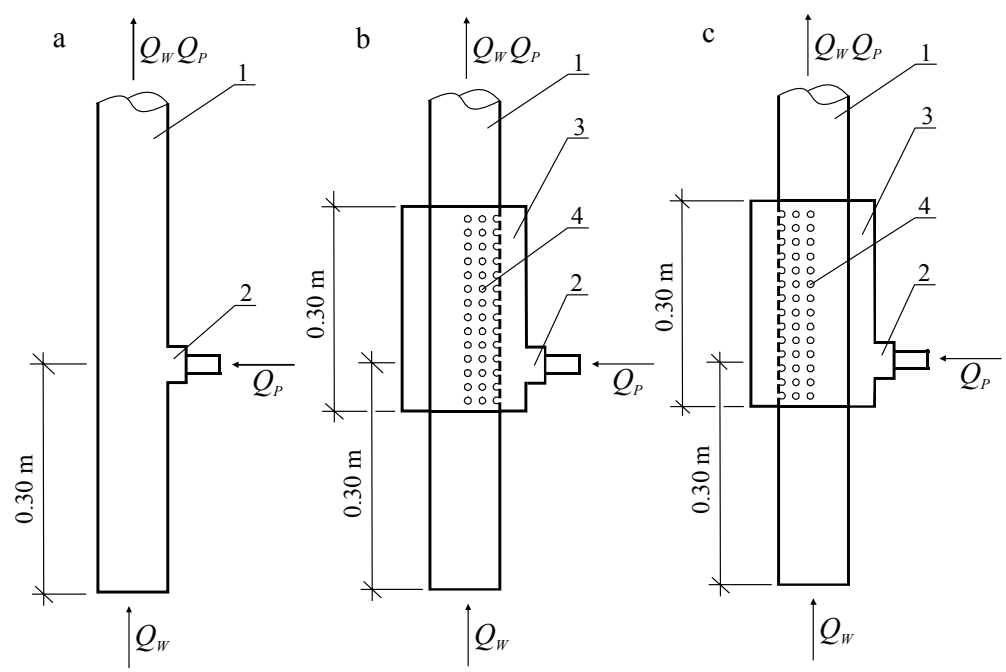

FIGURE 2. Construction of the air-water mixer: $\mathrm{a}-1$ type, $\mathrm{b}-2$ type $2, \mathrm{c}-3$ type, $1-$ transparent delivery pipe, 2 - steel end joining the elastic air supplying pipe, 3 - mixing chamber, 4 - holes

bottom edge of the delivery pipe (1) with the external diameter of $0.05 \mathrm{~m}$.

The $2^{\text {nd }}$ type mixer (Fig. 2b) has a form of a mixing chamber (3) with the internal diameter of $0.08 \mathrm{~m}$, tightly fastened on the delivery pipe (1) with the external diameter of $0.05 \mathrm{~m}$. The mixing chamber (3) along with the internal sealing has the external height of $0.30 \mathrm{~m}$ and the internal height of $0.25 \mathrm{~m}$. Its width, measured from the external wall of the delivery pipe (1) to the internal wall of the mixing chamber (3), is equal $0.03 \mathrm{~m}$. There are bored 70 holes (4) with the diameter of $0.004 \mathrm{~m}$, in five columns and fourteen rows, inside the mixing chamber (3) in a section of the delivery pipe (1). The holes (4) are placed at the half of the delivery pipe (1) circumference, on the side of the steel end (2) through which the air is pressed into the air lift pump.
The construction of the $3^{\text {rd }}$ type mixer (Fig. 2c) is almost the same as of the $2^{\text {nd }}$ type mixer. The difference consists in location of the holes (4) on the opposite side of the delivery pipe (1) circumference relative to the steel end (2) through which the air is pressed into the air lift pump. Such construction caused the pressure stabilization in the mixer chamber in the moment of air delivery to the mixer. It brought on a smooth air delivery through all the holes (4) in one time. The applied steel end (2) through which the air was pressed into the air lift pump was the same in each mixer's type. An elastic pipe (10 at the Fig. 1) was put on the steel end (2) to deliver the air.

At the pipeline (10, Fig. 1) with the internal diameter of $0.013 \mathrm{~m}$, which delivered the air from the compressor (23) to the air-water mixer (8), there are mounted the electronic air flow meter 
(19), electronic manometer (20), poppet valve (21) and ball cut-off valve (22).

The investigations were performed with the use of the Endress and Hauser devices. The electronic air flow meter (19) measuring range was from 0.0 to $25.0 \mathrm{~m}^{3} \cdot \mathrm{h}^{-1}$ and the electronic manometer (20) measuring range $-0-200 \mathrm{kPa}$. The air and water temperatures were not measured during the measurements, only on the beginning the water temperature was measured and it was equal $12^{\circ} \mathrm{C}$. The poppet valve (21) was used to regulate the air pressure.

During the measurements of the air lift pump delivery rate, there was used a plastic measuring tank (18) with the capacity of 1001 which was scaled at each 0.51 to the capacity of 501 . The measuring tank (18) served to measure the quantity of the water lifted by the air lift pump. The lifted water flew through the measuring tee (3), flew down to the measuring tank (18) through the water carrying pipe (4) with the internal diameter $0.04 \mathrm{~m}$. During the measurements on a given measuring tee (3), remaining tees were closed with cork (2).

\section{METHODOLOGY OF INVESTIGATIONS}

Before the measurements began on the constructed stand for investigations of the air lift pump (Fig. 1), air flows $\left(Q_{p}\right)$ had been determined for the assumed pressures $\left(p_{p}\right)$ of the air being delivered into the mixer (8): 102.0, 104.0, 108.0, $114.0,120.0,125.0 \mathrm{kPa}$. After start of the compressor (23) and opening of the ball valve (22), the assumed air pressure values were set up on the electronic manometer (20) with the use of the poppet valve (21). For the set values of air pressure (after their stabilization) the air flow values $\left(Q_{p}\right)$ were being read from the electronic air flow meter (19). Five measuring series were carried out, then the results were averaged by the arithmetic mean and the obtained air flow values $\left(Q_{p}\right)$, corresponding to the set air pressure values, were as follows: 0.5 , 1.5, 3.4, 5.6, 7.7, $9.9 \mathrm{~m}^{3} \cdot \mathrm{h}^{-1}$. Then, for the air flow values $\left(Q_{p}\right)$, determined in such way, the characteristics of delivery head and delivery rate were calculated for the three types of air-water mixers, applied in the air lift pump.

At the beginning of the measurement of delivery head $(H)$, the tank (7) had been filled with water, the compressor (23) was on and the required air pressure value was fixed by the poppet valve (21) - Figure 1. This air pressure value corresponded to the previously determined flow of the pressed air $\left(Q_{p}\right)$ according to the readings of the electronic air flow meter (19). The air lift pump delivery head $(H)$ was read after stabilization of the air-water mix flux in the delivery pipe (9). The reading of the delivery head $(H)$ was performed on the scale (24) placed on the delivery pipe (9). The scale (24) was made with the accuracy of $1 \mathrm{~cm}$. There was used a small ball with the smaller diameter than the delivery pipe (9) diameter to minimize the influence of the pulsatory character of the water flow through the delivery pipe (9) on the delivery head $(H)$, i.e. to increase the measurement accuracy. The ball was additionally loaded so as it was at the limit of buoyancy after throwing 
it into the delivery pipe (9). There was assumed that so loaded ball would well represent the air lift pump delivery head $(H)$ for the fixed flow of the delivered air $\left(Q_{p}\right)$. The ball was placed in the delivery pipe (9) each time before the measurement. Despite the ball was used, the pulsatory character of the water flow in the delivery pipe (9) caused that there was not possible to carry out the readings with the accuracy of $1 \mathrm{~cm}$. Due to this, the measurements of the water delivery head $(H)$ were made with the accuracy of $5 \mathrm{~cm}$. The reading of value of the height the ball had been lifted at was made after its stabilization on a given level, after at least $1 \mathrm{~min}$. The free surface of water in the tank (7) was kept on the constant lev- el during the measurements. The measurement was repeated five times, with one-minute intervals within one measuring series. Four measuring series were carried out for one type of the mixer. The obtained results of the air lift pump delivery head $(H)$, for the given air pressure, i.e. for the flow of the delivered air $\left(Q_{p}\right)$, are presented at Figure 3 .

At the beginning of the measurement of the air lift pump (Fig. 1) delivery rate $\left(Q_{w}\right)$, the tank (7) had been filled with water, the compressor (23) was on and the valve (22) was opened on the air supplying pipe (10) of the mixer (8). Then the required pressure value was fixed by the poppet valve (21) in dependence on the value of $Q_{p}$ for which the measurement

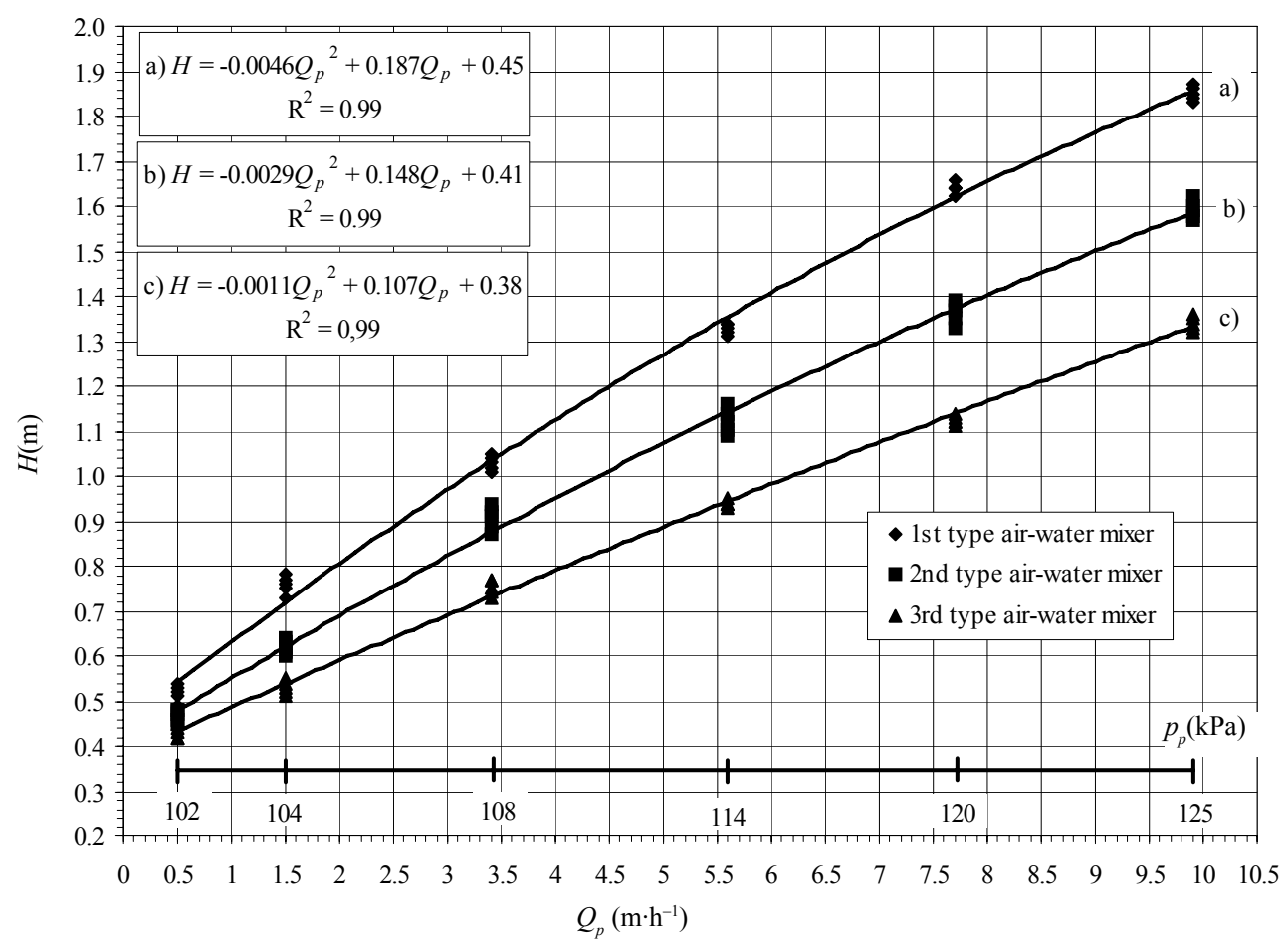

FIGURE 3. Water delivery heads in the air lift pump $(H)$ depending on the air flow $\left(Q_{p}\right)$ and air pressure $\left(p_{p}\right)$ 
was carried out. The check of the flow of delivered air $\left(Q_{p}\right)$ was carried out on the flow meter (19). After a determined air flow $\left(Q_{p}\right)$ had been set, a quantity of water, depending on the delivery rate $\left(Q_{w}\right)$, flew out from the tank (7). The water level in the tank (7) had to remain constant to make the measurement reliable. The change of the mixer submergence ratio and the change of the water level in the tank brings on significant changes both of the air lift pump delivery head $(H)$ and delivery rate $\left(Q_{w}\right)$. The ball valve (6) on the water supplying pipe (5) of the tank (7) was being opened once in a while to maintain the constant level of the liquid in the tank (7). The valve (6) each time was being set in the position which counterbalanced the water flow through a given measuring tee (3). The observation and regulation of the water level in the tank (7) was run relative to the level marked with a horizontal stroke on its internal wall. After that and after stabilization of the operating conditions of the air lift pump the measurement was began. The measuring container (18) was put under the water carrying pipe (4) and the water being lifted flew down to it through the water carrying pipe (4). The filling time, i.e. the measurement time, was fixed as one minute. As one minute passed, the measuring container (18) was moved away from under the water carrying pipe (4) and the reading was made on the scale (25). Then the measuring container (18) was being emptied by the opening of the ball valve (16) and the next air flow value $\left(Q_{p}\right)$ was being fixed. As the container (18) was empty, the ball valve (16) was being closed and the empty container (18) was put under the water carrying pipe (4) of the air lift pump. Three series of measurements were performed for the fixed air flow values $\left(Q_{p}\right)$ as well as for all of the five measuring tees (3) and three types of the mixers. The air lift pump delivery rate $\left(Q_{w}\right)$ was tested for five heights (Fig. 1): $0.45,0.90,1.35,1.80,2.25 \mathrm{~m}$, measured relative to the free water level in the tank (7). There were set the same values of $Q_{p}$ of pressed air as during the measurement of the delivery height $(H)$, i.e. $0.5,1.5$, $3.4,5.6,7.7,9.9 \mathrm{~m}^{3} \cdot \mathrm{h}^{-1}$. Thanks to such solution each of $Q_{w}$ corresponds to the measured value of $H$ for the same operating conditions.

\section{ANALYSIS OF THE OBTAINED RESULTS OF THE INVESTIGATIONS}

During operation of the air lift pump (Fig. 1) with the $1^{\text {st }}$ type mixer (Fig. 2a), the air flow in the transparent delivery pipe was observed in a form of big irregular bulbs which, in chaotic and turbulent flux, threw up the water on considerable height. The flux of the water flowing from the air lift pump was not continuous, but pulsatory and discontinuous. However, during operation of the air lift pump with the $2^{\text {nd }}$ type mixer (Fig. 2b), the air flow in the transparent delivery pipe was observed in a form of small regular bulbs which filled up the whole cross-section of the delivery pipe and evenly lifted the water up. The flux of the water flowing from the air lift pump was also pulsatory but not discontinuous. During operation of the air lift pump with the $3^{\text {rd }}$ type mixer (Fig. 2c), the air flow in the transparent delivery 
pipe was observed in a form of very tiny bulbs which built an air-water emulsion in the whole cross-section of the delivery pipe, whereas the flux of water flowing from the air lift pump was continuous with hardly visible pulsation.

The analysis of the obtained results of the water delivery head $(H)$ in dependence on the quantity of the pressed air $\left(Q_{p}\right)$ (Fig. 3) allows to state that the air lift pump delivery heads for each applied air-water mixer (Fig. 2) are comparable for small values of the air flow $\left(Q_{p}\right)$. It is proved by close positions of measuring points for the air flow value $Q_{p}=0.5 \mathrm{~m}^{3} \cdot \mathrm{h}^{-1}$. As the air flow value increases, the influence of the mixer construction on operating conditions of the air lift pump becomes visible. This influence is depicted by a radial character of run of the air lift pump water delivery head curves.

There was applied a mathematic model in a form of a polynomial of $2^{\text {nd }}$ degree to derive formulas describing the dependence of the air lift pump delivery rate $H$ on the air flow. High values of the coefficients of determination of the sample, which are ca. $\mathrm{R}^{2}=0.99$, mean that, for the obtained results of measurements, the air lift pump delivery rate $H$ depends in $99 \%$ on the air flow and the air pressure and only in $1 \%$ on other factors. Moreover, the obtained curves of water delivery rate tend to slope up in the whole investigated range of measurement.

If compare the measurement results of the water delivery height for the $1^{\text {st }}$ type mixer and for the $3^{\text {rd }}$ type mixer, then visibly protrudes a difference in effectiveness of delivery to the $3^{\text {rd }}$ type mixer's disadvantage. For the delivery rate $Q_{p}=0.5 \mathrm{~m}^{3} \cdot \mathrm{h}^{-1}$ one cannot state significant divergences between the two mixers because the obtained difference of the delivery heads is equal $0.09 \mathrm{~m}$, but for $Q_{p}=0.5 \mathrm{~m}^{3} \cdot \mathrm{h}^{-1}$ the delivery head obtained with the use of the $3^{\text {rd }}$ type mixer is lower by $0.24 \mathrm{~m}$ what constitutes $32 \%$ of fall of the air lift pump lifting potential in relation to the pump with the $1^{\text {st }}$ type mixer. The curve depicting the measurement results of the delivery head for the air lift pump with the $2^{\text {nd }}$ type mixer lays between the curves of the water delivery head for the air lift pump with the $1^{\text {st }}$ type mixer and with the $3^{\text {rd }}$ type one. Similarly as for the $3^{\text {rd }}$ type mixer, if compare the results of the water delivery head for the air lift pump with the $2^{\text {nd }}$ type mixer to those for the $1^{\text {st }}$ type mixer, the effectiveness of the delivery for low values of the air flow is small and equal a couple of centimeters. However, for the air flow $Q_{p}=1.5 \mathrm{~m}^{3} \cdot \mathrm{h}^{-1}$ the delivery head felt by $0.14 \mathrm{~m}$, what constitutes the reduction of delivery potential by $18 \%$.

The analysis of the measurement results from the point of view of air consumption shows that the air lift pump with the $1^{\text {st }}$ type mixer needs the lowest quantity of air to lift water at a given height. Assuming that a delivery head is equal $H=1 \mathrm{~m}$, the required air flow $\left(Q_{p}\right)$ should be equal for the mixers (Fig. $3)$ : of the $1^{\text {st }}$ type $-Q_{p}=3.2 \mathrm{~m}^{3} \cdot \mathrm{h}^{-1}$, of the $2^{\text {nd }}$ type $-Q_{p}=4.4 \mathrm{~m}^{3} \cdot \mathrm{h}^{-1}$, of the $3^{\text {rd }}$ type $-Q_{p}=6.2 \mathrm{~m}^{3} \cdot \mathrm{h}^{-1}$. If compared the required air flow in the air lift pump with the $2^{\text {nd }}$ and $3^{\text {rd }}$ type mixers to the air lift pump with the $1^{\text {st }}$ type mixer, one 
can state that in case of the $2^{\text {nd }}$ type mixer $27 \%$ more air is to be delivered to lift water at the height of $H=1 \mathrm{~m}$ and in case of the $3^{\text {rd }}$ type mixer $-48 \%$ more air.

To explain the differences between the delivery heads occurring for the three constructively different mixers (Fig. 2), an air flow velocity on the delivery pipe could not affect the differences arising in the measurement results.

The analysis of the test results presented at Figure 4 allows to state that in the delivery pipe of the air lift pump with the $1^{\text {st }}$ type mixer the air reaches the lowest flow velocity. It means that in the $1^{\text {st }}$ type mixer the air bulbs transfer their

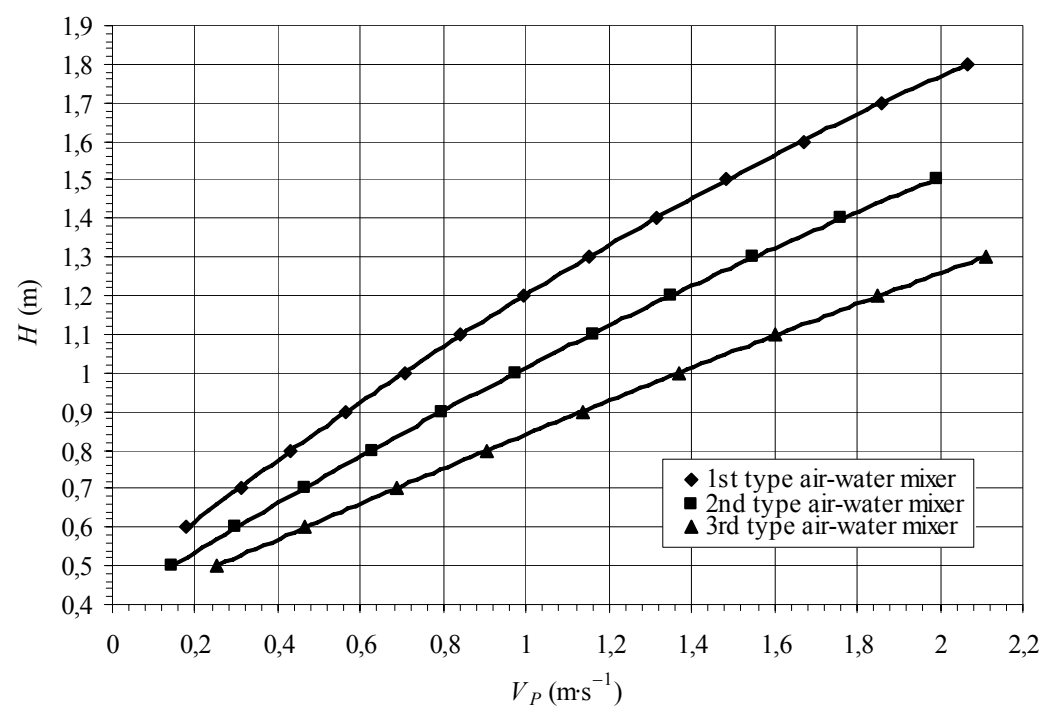

FIGURE 4. Water delivery heads in the air lift pump $(H)$ depending on the air flow velocity $\left(V_{p}\right)$

outlet was calculated for each mixer (Fig. 4) for the same delivery heads. According to theoretical assumptions, an air lift pump delivery head depends on a mixer submergence ratio, on the energy of an air flux on a delivery pipe outlet and on the losses resulting from friction forces (Jankowski 1975, Khalil et al. 1999, Kassab et al. 2009, Mahrous 2012, 2013a, Fan et al. 2013, Tighzert 2013). In the performed investigations the first and third parameters had the same values in the applied types of mixers, so they lifting energy in the highest degree to the water molecules, thus the air lift pump with the $1^{\text {st }}$ type mixer has the highest delivery head. However, in the air lift pump with the $3^{\text {rd }}$ type mixer, the air flow velocity in the delivery pipe reaches the highest flow velocity. It means that the air bulbs transfer their lifting energy in the lowest degree to the water molecules, what causes that the air lift pump with the $3^{\text {rd }}$ type mixer has the lowest delivery head. 
The Figure 5 presents the results of investigations of the delivery rate of the air lift pump in the dependence on the air flow. The analysis of the obtained results allows to state that the mixers applied in the air lift pump have influence on its delivery rate. The highest delivery rate is reached by the air lift pump with the $1^{\text {st }}$ type mixer, the lowest one - with the $3^{\text {rd }}$ type mixer. For the applied types of the mixers, the air lift pump delivery rate decreases with the rise in the delivery head and increases with the rise in the delivery rate.

To ensure that the water flows out from the air lift pump on required heights of delivery, an appropriate minimum air flow in the delivery pipe must be guaranteed. The minimum air flow $\left(Q_{p \min }\right)$ increases along with the rise in the delivery head $(H)$. Table 1 presents the minimum required air flow in the delivery pipe for fixed water delivery heads. For the fixed delivery head $H=1.8 \mathrm{~m}$, only for the $1^{\text {st }}$ type mixer the outflow was obtained; its delivery rate was equal $Q_{w}=2.17 \mathrm{dm}^{3} \cdot \mathrm{min}^{-1}$ with maximum fixed flow $Q_{p}=9.9 \mathrm{~m}^{3} \cdot \mathrm{h}^{-1}$. For the $2^{\text {nd }}$ and $3^{\text {rd }}$ type mixers, the outflow from the air lift pump was not observed for the fixed delivery head $H=1.8 \mathrm{~m}$. However, if for the applied mixers and fixed delivery heads $(H)$ the air flow in the investigated air lift pump exceeded
$Q_{p}=9.9 \mathrm{~m}^{3} \cdot \mathrm{h}^{-1}$, the air lift pump delivery rate $\left(Q_{w}\right)$ did not rise further but started to decrease. This phenomenon is known and described in literature (Khalil et al. 1999, Kassab et al. 2009, Hanafizadeh et al. 2011, Meng et al. 2013). It means that for the investigated air lift pump with the applied mixers (Fig. 2) the maximum required air flow should not exceed $Q_{p \max }=9.9 \mathrm{~m}^{3} \cdot \mathrm{h}^{-1}$.

In aim to determine the air lift pump flow capacity for each type of mixers, appropriate formulas were determined. In this order, with the use of the measurements, there was made out the graph (Fig. 5) where the functional dependence of the air flow $\left(Q_{p}\right)$ and water flow $\left(Q_{w}\right)$ on the water delivery head $(H)$ was determined. The analysis of the measurement results (Fig. 5) allows to state that every measuring points lay down close to each other, making visible tendencies for each water delivery head $(H)$. The observed tendency is described in the best way by the mathematical model in a form of a linear function and a $2^{\text {nd }}$ degree polynomial.

The coefficients of determination of the sample are greater than $\mathrm{R}^{2}=0.96$, what means that the water flow $\left(Q_{w}\right)$ in the air lift pump depends in $96 \%$ on the air flow $\left(Q_{p}\right)$ and the delivery head $(H)$ and only in $4 \%$ on other factors. Due to that, empirical formulas were made out

TABLE 1. List of minimum required air flow in the delivery pipe for fixed delivery heads

\begin{tabular}{|l|c|c|c|}
\hline Parameters & \multicolumn{3}{|c|}{ Minimum required air flow, $Q_{p \min }\left(\mathrm{m}^{3} \cdot \mathrm{h}^{-1}\right)$} \\
\hline Fixed delivery head $H(\mathrm{~m})$ & 0.45 & 0.90 & 1.35 \\
\hline $1^{\text {st }}$ type air-water mixer & 0.5 & 1.5 & 5,6 \\
\hline $2^{\text {nd }}$ type air-water mixer & 0.5 & 1.5 & 5.6 \\
\hline $3^{\text {rd }}$ type air-water mixer & 0.5 & 3.4 & 7.7 \\
\hline
\end{tabular}




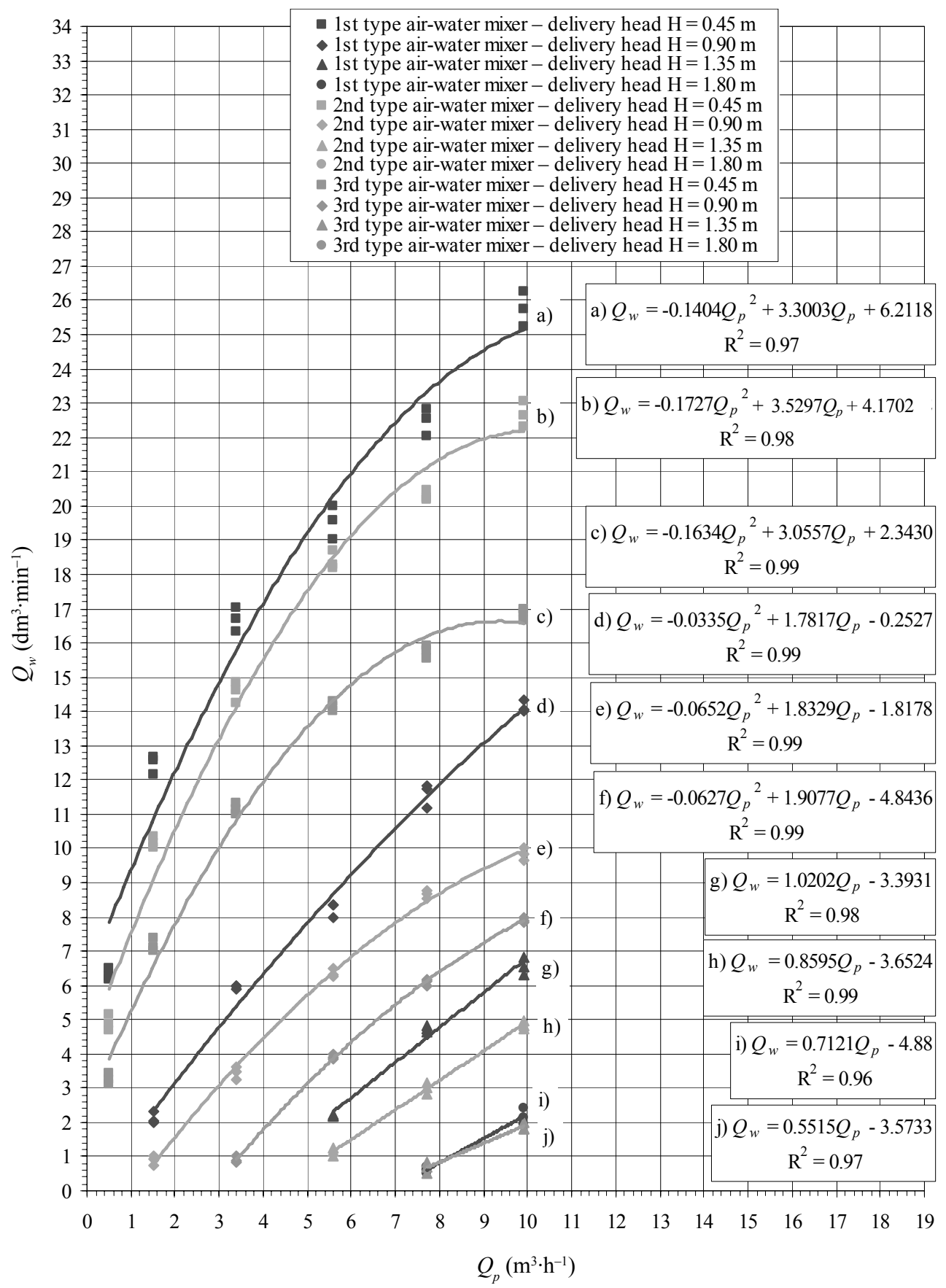

FIGURE 5. Delivery rate of the air lift pump $\left(Q_{w}\right)$ in a dependence on the air flow $\left(Q_{p}\right)$ in the delivery pipe 
in the dependence on the air flow $\left(Q_{p}\right)$ and delivery head $(H)$ to calculate the water flow $\left(Q_{w}\right)$ - Figure 5 .

Then, using the determined formulas, the efficiency of the air lift pumps with each type of air-water mixers was calculated. The analysis of the obtained results (Fig. 6) allows to state that the air lift pump efficiency $(\eta)$ for the three investigated types of air-water mixers very quickly falls almost to zero if the air flow rate $\left(Q_{p}\right)$ rises. It is caused by the fact that when the air flow rate $\left(Q_{p}\right)$ rises then more air bubbles occur in the delivery pipe of the air lift pump and these bubbles occupy more space in the delivery pipe cross-section, therefore the space occupied by water has less share in the delivery pipe cross-section. But the rise in the air flow rate $\left(Q_{p}\right)$ in the delivery pipe causes the rise in the water flow rate what in turn causes the friction increase and efficiency decrease. The efficiency $(\eta)$ of the air lift pump for the three investigated types of the air-lift mixers decreases with the rise in the water delivery head $(H)$ as well. It is caused by the increase of linear hydraulic re-

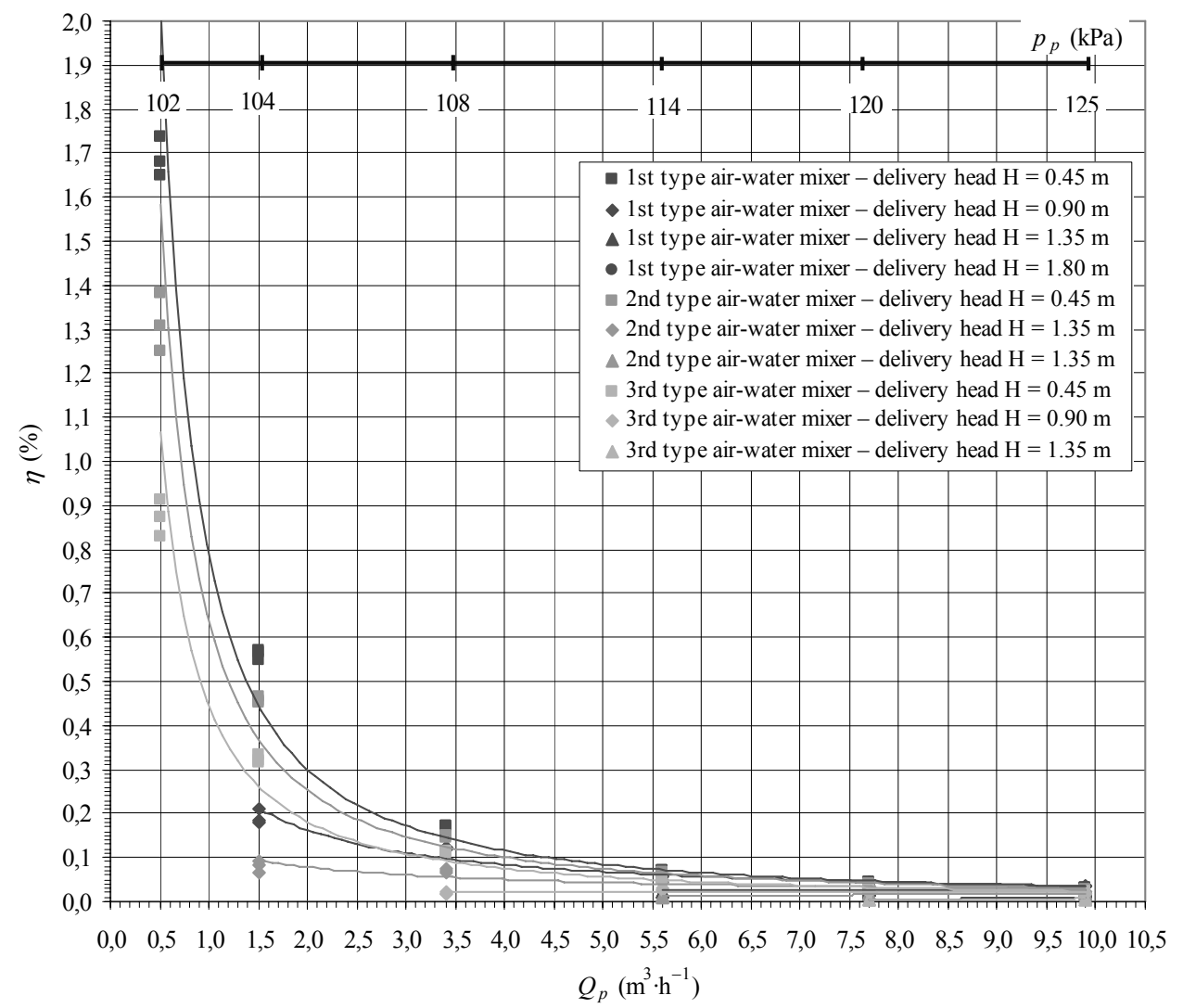

FIGURE 6. Efficiency $(\eta)$ of the air lift pump depending on the air flow rate $\left(Q_{p}\right)$ and air pressure $\left(p_{p}\right)$ 
sistance along the delivery pipe length and by the decrease of the water flow rate $\left(Q_{w}\right)$. The highest efficiency $(\eta)$ (Fig. 6) is reached by the air lift pump with the $1^{\text {st }}$ type air-water mixer (Fig. 2) and the lowest - with the $3^{\text {rd }}$ type air-water mixer.

Using the measurement results presented on the Figure 3 the delivery pipe submergence ratio $(h / L)$ was determined for the three types of air-water mixers applied in the air lift pump. Then, using the results of measurement of air flow rate $\left(Q_{p}\right)$ and water flow rate $\left(Q_{w}\right)$, presented on the Figure 3, as well as the improved analytical Stenning-Martin model, constructed of the Eqs. (2), (3), (4), (5), (6) and (7), the delivery pipe submergence ratio $(h / L)$ was determined for the three types of air-water mixers. The obtained results of the delivery pipe submergence ratio from the measurements and from calculations with the Stenning-Martin model are presented on the Figure 7.

The analysis of the obtained results (Fig. 7) allows to state that the values obtained from the measurements of the delivery pipe submergence ratio $(h / L)$ were the highest for the $3^{\text {rd }}$ type air-water mixer and the lowest for the $1^{\text {st }}$ type

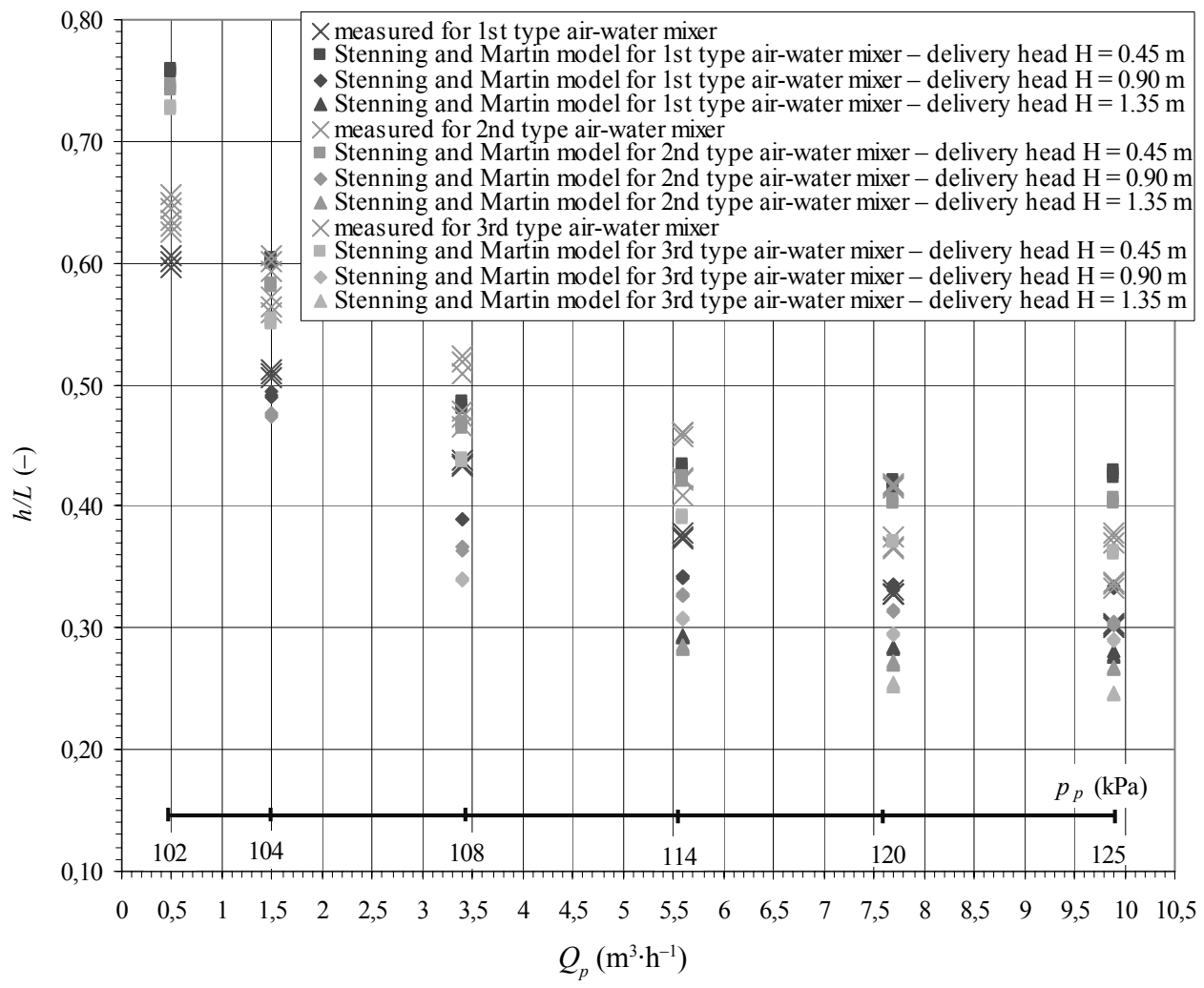

FIGURE 7. Delivery pipe submergence ratio $(h / L)$ depending on the air flow rate $\left(Q_{p}\right)$ and air pressure $\left(p_{p}\right)$ 
mixer. However, the values of $h / L$ calculated from the Stenning-Martin model run in the reverse way: the highest values were obtained for the $1^{\text {st }}$ type air-water mixer and the lowest - for the $3^{\text {rd }}$ type mixer. Taking into consideration the fact that the flow of the two-phase mix in the investigated air lift pump with the three types of air-water mixers is pulsatory and very various, one can state that the values of $h / L$ calculated from the Stenning-Martin model quite well coincide with the values of $h / L$ determined from the measurements.

\section{CONCLUSIONS}

1. It results from the performed investigations that the air lift pump with the $1^{\text {st }}$ type mixer lifts water on the highest level and the one with the $3^{\text {rd }}$ type mixer - on the lowest level. The air lift pump delivery head depends on quantity of the air pressed into the air-water mixer, i.e. on the air flow in the delivery pipe.

2. The air lift pump delivery head increases along with the rise in the air pressed into the mixer. The water delivery head depends also on the hydraulic losses generated during flow of the air flux through the mixer. The greater are the air hydraulic losses, the lower is the air lift pump delivery head.

3. The highest delivery rate in the water transport was reached by the air lift pump with the $1^{\text {st }}$ type air-water mixer, the lowest one - with the $3^{\text {rd }}$ type air-water mixer. The water flow in the air lift pump increases along with the rise in the air flow. The lower are the hydraulic losses generated during flow of the air flux by the air-water mixer, the higher is the air lift pump capacity. Along with the rise in the water delivery head, the capacity of the air lift pump decreases.

4. The highest efficiency $(\eta)$ is reached by the air lift pump with the $1^{\text {st }}$ type air-water mixer and the lowest - with the $3^{\text {rd }}$ type air-water mixer. The air lift pump efficiency $(\eta)$ for the three investigated types of air-water mixers decreases along with the increase of the air flow rate and with the rise in the water delivery head.

5. The values of the delivery pipe submergence ratio $(h / L)$ calculated from the improved Stenning-Martin model quite well coincide with the values of $h / L$ determined from the measurements. Thus, the improved Stenning-Martin model can be applied to design air lift pumps with the air-water mixers of this type (Fig. 2).

\section{REFERENCES}

BARRUT B., BLANCHETON J-P., CHAMPAGNE J.-Y., GRASMICK A. 2012: Mass transfer efficiency of a vacuum air lift-application to water recycling in aquaculture systems. Aquacultural Engineering 46, 18-26.

De CACHARD F., DELHAYE J.M. 1996: A slug-churn flow model for small-diameter airlift pumps. Int. J. Multiphase Flow. 22 (4), 627-649.

ESEN I.I. 2010: Experimental investigation of a rectangular air lift pump. Hindawi Publishing Corporation. Advances in Civil Engineering. ID 789547, 5. doi:10.1155/2010/789547.

FAN W., CHEN J., PAN Y., HUANG H., CHEN C.-T.A., CHEN Y. 2013: Experimental study on the performance of air-lift pump for artificial upwelling. Ocean Engineering 59, 47-57. 
FUJIMOTO H., MURAKAMI S., OMURA A., TAKUDA H. 2004: Effect of local pipe bends on pump performance of a small air-lift system in transporting solid particles. International Journal of Heat and Fluid Flow 25, 996-1005.

HANAFIZADEH P., GHANBARZADEH S., SAIDI M.H. 2011: Visual technique for detection of gas-liquid two-phase flow regime in the air lift pump. Journal of Petroleum Science and Engineering 75, 327-335.

HEIDRICH Z., KALENIK M., PODEDWORNA J., STAŃKO G. 2008: Sanitacja wsi [Public health on rural areas]. Wydawnictwo Seidel-Przywecki, Warszawa (in Polish).

JANKOWSKI F. 1975: Pompy i wentylatory w inżynierii sanitarnej. [Pumps and ventilators in sanitary engineering]. Arkady, Warszawa (in Polish).

KALENIK M. 2008: Experimental investigations of hydraulic resistance on lifts in pipelines of a vacuum sewage system. Environment Protection Engineering 3 (34), 59-73.

KALENIK M. 2009: Zaopatrzenie w wodę i odprowadzanie ścieków. [Water supply and sewage disposal]. Wydawnictwo SGGW, Warszawa (in Polish).

KALENIK M. 2014: Experimental investigations of interface valve flow capacity in the RoeVac type vacuum sewage system. Environment Protection Engineering 3 (40), 127-138.

KHALIL M.F., ELSHORBAGY K.A., KASSAB S.Z., FAHMY R.I. 1999: Effect of air injection method on the performance of an air lift pump. International Journal of Heat and Fluid Flow 20 (1), 598-604.

KASSAB S.Z., KANDIL H.A., WARDA H.A., AHMED W.H. 2007: Experimental and analytical investigations of airlift pumps operating in three-phase flow. Chemical Engineering Journal 131, 273-281.

KASSAB S.Z., KANDIL H.A., WARDA H.A., AHMED W.H. 2009: Air-lift pumps characteristics under two-phase flow conditions. International Journal of Heat and Fluid Flow 30, 88-98.

KIM S.H., SOHN C.H., HWANG J.Y. 2014: Effects of tube diameter and submergence ratio on bubble pattern and performance of air-lift pump. International Journal of Multiphase Flow 58, 195-204.

MAHROUS A.-F. 2012: Numerical Study of Solid Particles-Based Airlift Pump Performance. Wseas Transactions on Applied and Theoretical Mechanics 3 (7), 221-230.

MAHROUS A.-F. 2013a: Experimental study of airlift pump performance with s-shaped riser tube bend. I. J. Engineering and Manufacturing 1, 1-12.

MAHROUS A.-F. 2013b: Performance study of an air-lift pump with bent riser tube. Wseas Transactions on Applied and Theoretical Mechanics 2 (8), 136-145.

MAHROUS A.-F. 2014: Performance of airlift pumps: single-stage $v s$. multistage air injection. American Journal of Mechanical Engineering 2 (1), 28-33.

MENG Q., WANG C., CHEN Y., CHEN J. 2013: A simplified CFD model for air-lift artificial upwelling. Ocean Engineering 72, 267-276.

NICKLIN D.J. 1963: The air lift pump: theory and optimization. Trans. Inst. Chem. Eng. 41, 29-39.

PARKER N.C. 1983: Airlift pumps and other aeration techniques. In: Water quality in channel catfish ponds. Ed. C.S. Tucker. Southern Cooperative Series Bulletin 290. Mississippi Agriculture and Forestry Experiment Station, Mississippi State University, Mississippi, 24-27.

SOLECKI T. 2010: Analiza i ocean możliwości renowacji odwiertu w uzdrowisku Połczyn. [Analysis and evaluation of renovation possibilities of a wellbore in Połczyn health resort]. Wiertnictwo - Nafta - Gaz 3 (27), 617-627 (in Polish).

TIGHZERT H., BRAHIMI M., KECHROUD N., BENABBAS F. 2013: Effect of submergence ratio on the liquid phase velocity, efficiency and void fraction in an air-lift pump. Journal of Petroleum Science and Engineering 110, 155-161.

WAHBA E.M., GADALLA M.A., ABUEIDDA D., DALAQ A., HAFIZ H., ELAWADI K., ISSA R. 2014: On the performance of air-lift pumps: from analytical models to large eddy simulation. Journal of Fluids Engineering 11 (136)/111301, 1-7. 
WURTS W.A., MCNEILL S.G., OVERHULTS D.G. 1994: Performance and design characteristics of air lift pumps for field applications. World Aquaculture 25 (4), 51-55.

YOSHINAGA T., SATO Y. 1996: Performance of an air-lift pump for conveying coarse particles. Int. J. Multiphase Flow 22 (2), 223-238.

Streszczenie: Badania hydraulicznych warunków pracy powietrznego podnośnika z trzema typami mieszaczy powietrzno-wodnych. $\mathrm{W}$ artykule przedstawiono analizę wyników badań, dotyczących wpływu różnych rozwiązań konstrukcyjnych mieszaczy powietrzno-wodnych na hydrauliczne warunki pracy powietrznego podnośnika. Badania obejmowały wyznaczenie charakterystyk wysokości podnoszenia i wydajności dla trzech typów mieszaczy powietrzno-wodnych zastosowanych $\mathrm{w}$ wybudowanym powietrznym podnośniku. Wykorzystując uzyskane wyniki badań, wyznaczono sprawność dla trzech typów mieszaczy powietrzno-wodnych zastosowanych w wybudowanym powietrznym podnośniku. Przeprowadzono analizę i sprawdzono, czy udoskonalony analityczny model Stenninga i Martina może być wykorzystywany do projektowania powietrznych podnośników z tego typu mieszaczami powietrzno-wodnymi. Największą wydajność $\mathrm{w}$ transporcie wody powietrzny podnośnik osiagnął z mieszaczem powietrzno-wodnym typu 1, a najmniejszą z mieszaczem typu 3. Przepływ wody w powietrznym podnośniku rośnie wraz ze wzrostem natężenia przepływu powietrza. Im mniejsze straty hydrauliczne są generowane podczas przepływu strumienia powietrza przez mieszacz powietrzno-wodny, tym wydajność powietrznego podnośnika jest większa. Wraz ze wzrostem wysokości podnoszenia wody wydajność powietrznego podnośnika maleje. Największą sprawność powietrzny podnośnik osiąga $\mathrm{z}$ mieszaczem typu 1, a najmniejszą z mieszaczem typu 3. Sprawność podnośnika powietrznego dla trzech badanych typów mieszaczy powietrzno-wodnych maleje wraz ze wzrostem natężenia przepływu powietrza i wysokości podnoszenia wody. Obliczone wartości stosunku zanurzenia rurociagu tłocznego $(h / L)$ za pomocą udoskonalonego analitycznego modelu Stenninga i Martina dość dobrze pokrywają się z wartościami $h / L$ wyznaczonymi z pomiarów.

Słowa kluczowe: powietrzny podnośnik (pompa Mamut), mieszacz powietrzno-wodny, przepływ wody, przepływ powietrza

\section{MS. received October 2014}

\author{
Author's address: \\ Marek Kalenik \\ Szkoła Główna Gospodarstwa Wiejskiego \\ Wydział Budownictwa i Inżynierii Środowiska \\ Katedra Inżynierii Budowlanej \\ Zakład Wodociągów i Kanalizacji \\ ul. Nowoursynowska 159, 02-776 Warszawa \\ Poland \\ e-mail: marek_kalenik@sggw.pl
}

